\title{
Fetal distress and in utero pneumonia in perinatal dolphins during the Northern Gulf of Mexico unusual mortality event
}

\author{
Kathleen M. Colegrove ${ }^{1, *}$, Stephanie Venn-Watson ${ }^{2}$, Jenny Litz ${ }^{3}$, Michael J. Kinsel ${ }^{2}$, \\ Karen A. Terio ${ }^{2}$, Erin Fougeres ${ }^{4}$, Ruth Ewing ${ }^{3}$, D. Ann Pabst ${ }^{5}$, William A. McLellan ${ }^{5}$, \\ Stephen Raverty ${ }^{6}$, Jeremiah Saliki ${ }^{7}$, Spencer Fire ${ }^{8,17}$, Gina Rappucci ${ }^{9}$, \\ Sabrina Bowen-Stevens ${ }^{9}$, Lauren Noble ${ }^{10}$, Alex Costidis ${ }^{5}$, Michelle Barbieri ${ }^{11,18}$, \\ Cara Field ${ }^{12,18}$, Suzanne Smith ${ }^{12}$, Ruth H. Carmichael ${ }^{13}$, Connie Chevis $^{14}$, \\ Wendy Hatchett ${ }^{14}$, Delphine Shannon ${ }^{14}$, Mandy Tumlin ${ }^{15}$, Gretchen Lovewell ${ }^{16}$, \\ Wayne McFee ${ }^{8}$, Teresa K. Rowles ${ }^{11}$ \\ ${ }^{1}$ Zoological Pathology Program, College of Veterinary Medicine, University of Illinois at Urbana-Champaign, Maywood, \\ IL 60153, USA
}

For list of author affiliations, see Appendix

\begin{abstract}
An unusual mortality event (UME) involving primarily common bottlenose dolphins Tursiops truncatus of all size classes stranding along coastal Louisiana, Mississippi, and Alabama, USA, started in early 2010 and continued into 2014. During this northern Gulf of Mexico UME, a distinct cluster of perinatal dolphins (total body length $<115 \mathrm{~cm}$ ) stranded in Mississippi and Alabama during 2011. The proportion of annual dolphin strandings that were perinates between 2009 and 2013 were compared to baseline strandings (2000-2005). A case-reference study was conducted to compare demographics, histologic lesions, and Brucella sp. infection prevalence in 69 UME perinatal dolphins to findings from 26 reference perinates stranded in South Carolina and Florida outside of the UME area. Compared to reference perinates, UME perinates were more likely to have died in utero or very soon after birth (presence of atelectasis in 88 vs. $15 \%$, p < $0.0001)$, have fetal distress ( 87 vs. $27 \%, p<0.0001)$, and have pneumonia not associated with lungworm infection ( 65 vs. $19 \%, p=0.0001$ ). The percentage of perinates with Brucella sp. infections identified via lung PCR was higher among UME perinates stranding in Mississippi and Alabama compared to reference perinates ( $61 \mathrm{vs.} 24 \%, \mathrm{p}=0.01$ ), and multiple different Brucella omp genetic sequences were identified in UME perinates. These results support that from 2011 to 2013, during the northern Gulf of Mexico UME, bottlenose dolphins were particularly susceptible to late-term pregnancy failures and development of in utero infections including brucellosis.
\end{abstract}

KEY WORDS: Bottlenose dolphin - Brucella $\cdot$ Fetal distress $\cdot$ Fetal loss $\cdot$ Oil spill $\cdot$ Pneumonia Tursiops truncatus $\cdot$ Unusual mortality event

\section{INTRODUCTION}

The largest and longest cetacean unusual mortality event (UME) on record in the Gulf of Mexico (GoM) was declared from Louisiana through the Florida panhandle (Franklin County), USA, starting in early

\footnotetext{
${ }^{*}$ Corresponding author: katie.colegrove@gmail.com
}

2010 and continuing into 2014 (Litz et al. 2014). Strandings have been primarily of common bottlenose dolphins Tursiops truncatus, hereafter referred to as 'dolphins', and concentrated in Louisiana, Mississippi, and Alabama (Venn-Watson et al. 2015a). During February through April 2011, a large propor-

() The authors 2016. Open Access under Creative Commons by Attribution Licence. Use, distribution and reproduction are unrestricted. Authors and original publication must be credited. 
tion of the stranded dolphins in Mississippi and Alabama were perinates (<115 cm body length) (Carmichael et al. 2012, Venn-Watson et al. 2015a). Although perinatal bottlenose dolphin strandings typically increase in the northern GoM from January through April every year due to peaks in dolphin calving, the proportion of perinatal strandings during 2011 was elevated above baseline (Worthy 1998, Mattson et al. 2006, Pitchford et al. 2013, Litz et al. 2014, Venn-Watson et al. 2015a).

There are a number of possible causes for dolphin UMEs but few specific to perinatal strandings, which are poorly understood. The majority of previous dolphin GoM UMEs were confirmed or suspected to be caused by either brevetoxicosis or morbillivirus (Litz et al. 2014). Historically, causes of GoM dolphin perinatal deaths, both during expected spring calving peaks and UME years, are not well understood. Primary limitations to previous investigations of perinatal dolphin mortalities have included poor carcass detection and recovery, poor carcass condition, subsequent lack of histologic examinations, and lack of available molecular diagnostic assays targeting specific pathogens. Recently, 2 UMEs that occurred in Texas during the spring of 2007 and 2008 involved elevated numbers of stranded perinatal dolphins (Fire et al. 2011, Litz et al. 2014). In these cases, infectious disease was suspected but, due to poor carcass condition and lack of available tissue for ancillary testing, could not be confirmed (Litz et al. 2014).

Brucella is a gram-negative, intracellular bacterium, which has been isolated from many marine mammal species globally (Nymo et al. 2011, Guzmán-Verri et al. 2012, Hernández-Mora et al. 2013). In cetaceans, Brucella sp. may cause placentitis and sporadic late-term abortion, and bacteria have been isolated from reproductive tract lesions (Miller et al. 1999, Dagleish et al. 2008, Guzmán-Verri et al. 2012, Hernández-Mora et al. 2013). Additional lesions associated with brucellosis in cetaceans include meningoencephalitis, osteomyelitis, and lung granulomas and abscesses (Dagleish et al. 2008, Goertz et al. 2011, Guzmán-Verri et al. 2012, Cassle et al. 2013, Davison et al. 2013). A novel introduction of Brucella, an alteration of Brucella to increase its virulence, or point-source exposure of populations to Brucella have not been previously identified as causes of epizootics or perinatal die-offs in marine mammals. The role that Brucella plays in free-ranging dolphin perinate mortalities is largely unknown.

On April 20, 2010, 3 mo after the UME's declared start date of February 1, 2010, the Deepwater Horizon (DWH) oil spill occurred (McNutt et al. 2012). Bara- taria Bay, Louisiana, was one of the most severely impacted coastal areas, and both coastal Mississippi and Alabama were also affected (Michel et al. 2013). Freeranging Barataria Bay bottlenose dolphins evaluated during live health assessments in August 2011 had evidence of severe lung disease and blood abnormalities consistent with hypoadrenocorticism (Schwacke et al. 2014). During the current UME, non-perinatal dolphins dying from 2010 through 2012 had a higher prevalence of primary bacterial pneumonia and adrenal cortical atrophy compared to reference dolphins (Venn-Watson et al. 2015b). Exposure to contaminants from the DWH oil spill has been proposed as a potential cause of or contributor to adrenal and lung disease (Schwacke et al. 2014, Venn-Watson et al. 2015b). The impact of potential oil exposure on reproductive success of dolphins is unknown.

The goal of this investigation was to better understand potential causes of the ongoing northern GoM UME, specifically among perinatal dolphins, by comparing the epidemiology and pathologic findings of perinatal dolphins that stranded in Louisiana, Mississippi, and Alabama from 2010 through 2013 to those in baseline and reference populations. GoM UME perinatal dolphins were also tested for evidence of biotoxin exposure and morbillivirus infection, which are known causes for previous mortality events in the GoM. Further, as Brucella sp. is a known cause of abortion in cetaceans, the prevalence of Brucella sp. infection detected by PCR was compared between UME and reference perinate bottlenose dolphins (Miller et al. 1999, Guzmán-Verri et al. 2012).

\section{MATERIALS AND METHODS}

\section{Stranded GoM perinate dolphin demographics}

Dolphins included as UME cases in this study were perinates that stranded as whole carcasses, with a reported total body length $<115 \mathrm{~cm}$ in Louisiana, Mississippi, and Alabama, USA, from January 1, 2010 through December 31, 2013 (Fig. 1). Mattson et al. (2006) demonstrated that in this region estimated dolphin lengths at birth are 90-103 cm for females and 100-107 $\mathrm{cm}$ for males, supporting the idea that dolphins $<115 \mathrm{~cm}$ are those that stranded soon after being aborted or born live. Stranding data from Louisiana, Mississippi, and Alabama collected between 2000 and 2005 were used to determine the baseline prevalence of dolphin strandings that were perinates in the northern GoM (hereafter referred to as 'baseline'). Since historically there are consistent 


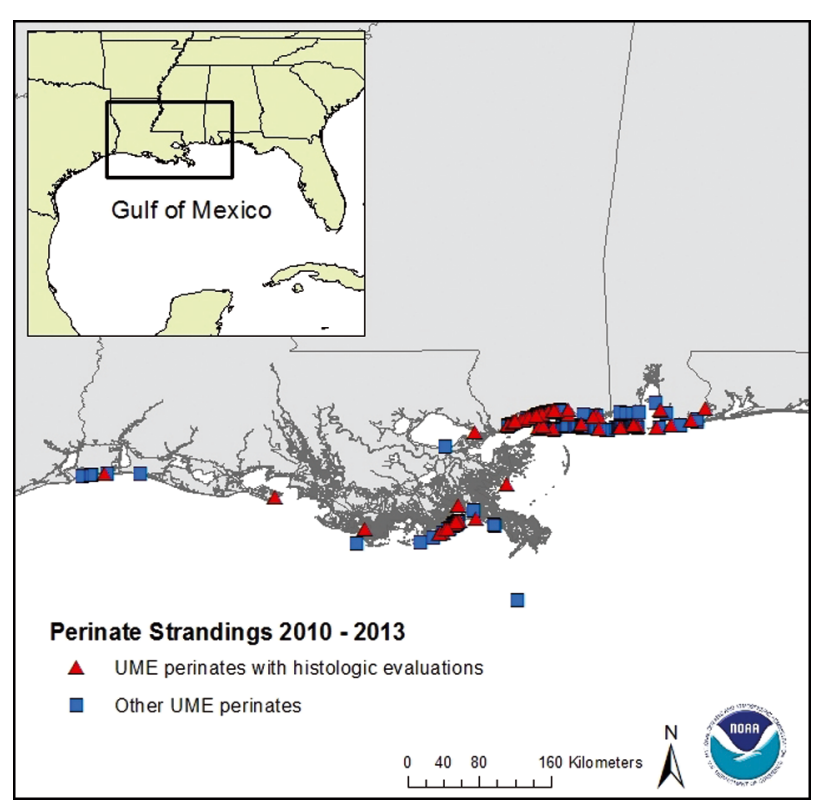

Fig. 1. Perinate stranding locations from Alabama, Mississippi, and Louisiana, USA, from 2010 to 2013. Unusual mortality event (UME) perinates with histologic evaluations included as cases in this investigation in red; UME perinates without histologic evaluations but used in the demographic comparisons in blue

spring peaks in the number of stranded perinates in the northern GoM from the months of January through April, coinciding with the calving season, the prevalence of UME and baseline stranded dolphin perinates was compared by limiting the scope to the months of January through April (Mattson et al. 2006, Pitchford et al. 2013). Statistical comparisons of the prevalence of stranded dolphin perinates (baseline [2000-2005] vs. 2009, 2010, 2011, 2012, and 2013 by state) were conducted using chi-square tests. The year 2009 was included to assess potential trends in the prevalence of perinatal strandings before 2010 . The years 2006-2008 were excluded from the baseline, as the area was heavily impacted by Hurricane Katrina in August 2005, greatly reducing surveillance for stranded dolphins (Pitchford et al. 2013).

Data including stranding date and location, body length, sex, and carcass condition were collected using a standardized Level-A data record (National Oceanic and Atmospheric Administration [NOAA] Form 89-864 (rev.2007) OMB No. 0648-0178). Final Level-A data from baseline (2000-2005) and the 2009-2013 period were extracted from the NOAA Marine Mammal Health and Stranding Response Program National Database during March 2015. Only stranded dolphins with recorded body lengths were included in this study. For 2009-2013, dolphins with a reported body length $<115 \mathrm{~cm}$ that were not reported as a whole carcass were excluded for the demographic comparisons. Previous to 2007, it was not recorded if carcass lengths were for whole or partial carcasses, so all dolphins with recorded lengths were included. This potential bias, if any, would increase the prevalence of shorter-length dolphins during the baseline period. Body lengths were compared between UME and reference study sets using Wilcoxon rank-sum tests. Significance was defined as a p-value $<0.05$. Carcass condition codes were assigned based on definitions established in Geraci \& Lounsbury (1993).

\section{Gross necropsy evaluation}

Post mortem examinations of stranded UME perinates were conducted by members of the United States Marine Mammal Stranding Network either in the field or at institutional facilities. Of the $69 \mathrm{UME}$ perinatal dolphins with histologic evaluations included in this study, 57 (83\%) were evaluated grossly using a standardized perinate form specifically developed to record the presence or absence of grossly observable perinate dolphin characteristics. Pulmonary atelectasis was determined grossly based on whether the lungs sank or floated in formalin. Lungs that sank were regarded as grossly atelectic, and lungs that floated were non-atelectic. To further characterize the developmental status of the perinates, the prevalence of the presence or absence of the following gross perinatal characteristics were assessed using a standardized datasheet: fetal skin folds, rostral hairs, hair follicles, erupted maxillary teeth, erupted mandibular teeth, lingual papillae, nuchal dent, folded dorsal fin, creased dorsal fin, dent proximal to blowhole, open ductus arteriosus, open or healed umbilicus, and presence of meconium.

\section{Histologic evaluations - case-reference study}

A total of $64 \mathrm{UME}$ perinatal dolphins that stranded as whole carcasses along coastal Louisiana, Mississippi, and Alabama between February 2010 and December 2013 had at least the lung available for evaluation. In addition, photographs were reviewed from 7 partial carcasses in which histology was available. Of those 7 cases, 5 carcasses had lengths that were determined to be $<115 \mathrm{~cm}$ despite missing tissue; therefore, 69 total perinatal dolphins were included in the case-reference study. Additionally, 
archived histopathology reports or hematoxyalin and eosin stained slides from 26 reference perinatal (<115 cm total length) dolphins were evaluated to compare the prevalence of lesions between UME and reference perinatal dolphins. Reference perinatal dolphins stranded outside the UME area in South Carolina (1996-2012) and the east and west coasts of Florida (2002-2009) and were selected based on availability of histopathologic reports and/or slides.

Tissue samples from UME and reference perinatal dolphins were collected and stored in $10 \%$ neutral buffered formalin. The tissues were processed routinely, embedded in paraffin, sectioned at $5 \mu \mathrm{m}$, and stained using hematoxylin and eosin (H\&E). Two pathologists (K. M. Colegrove and M. J. Kinsel) evaluated UME and reference cases with a consensus on the grading scheme. For lung evaluations, cases with lung lesions diagnosed histologically were defined as 'abnormal lung'. Pulmonary atelectasis was graded histologically as partial or complete depending on the number of alveolar spaces or bronchioles that were expanded by clear space (air). Fetal distress was defined as amniotic squamous cells within bronchioles and alveoli, increased in number above the small numbers normally found at birth, and with or without meconium (Gould 2007). Severity of fetal distress was graded subjectively as mild, moderate, or severe depending on the amount of amniotic squamous cells and/or meconium present in the lung and the extent of bronchioles and alveolar spaces affected. Inflammation indicative of pneumonia was graded subjectively as mild, moderate, or severe depending on the number and extent of inflammatory cells present. Pneumonias were sub-classified as 'in utero infection other than lungworm' if pulmonary inflammation was present in combination with histologically identified atelectasis and/or fetal distress and lung parasites were not present.

Statistical comparisons of the prevalence of histopathologic lung lesions (abnormal lung, atelectasis, fetal distress, and pneumonia), lung-positive for Brucella sp. via PCR, and sex among UME and reference perinatal dolphins were conducted using chi-square tests if adequate numbers were available and by Fisher's exact tests if any frequency was $<5$. Comparisons were also made between the prevalence of lung lesions, lung-positive for Brucella sp. via PCR, and sex among perinatal dolphins stranding in Louisiana versus Mississippi and Alabama to evaluate potential geographic and demographic differences. Odds ratios (OR) were calculated only if all cell frequencies were $\geq 5$. Body length was compared between UME dolphins in which histopathology was completed and reference perinates using a Wilcoxon rank-sum test. Significance was defined as a p-value $<0.05$.

\section{Immunohistochemistry}

Immunohistochemistry was completed on lung from 6 UME perinates (5 Brucella PCR-positive, 1 Brucella PCR-negative) with pneumonia of varying severity. Slides were rehydrated, and antigen retrieval was performed using a retrieval solution (Diva Decloaker, Biocare) at $121^{\circ} \mathrm{C}$ for $10 \mathrm{~min}$ in a pressurized chamber. The slides were blocked with normal goat serum, followed by antigen detection, using a rabbit polyclonal antibody to $B$. abortus (provided by Dr. Steven Olsen, National Animal Disease Center) diluted 1:1500 as the primary antibody. An automated immunohistochemical stainer was utilized (Leica BOND-MAX). Color was developed using a polymeric alkaline phosphatase system (Leica Bond ${ }^{\mathrm{TM}}$ Polymer Refine Red Detection) and counterstained with hematoxylin. Negative control slides were bovine tissues with non-Brucella bacterial granulomas. Positive controls were tissue from a bison infected with $B$. abortus.

\section{Brucella PCR}

DNA was extracted from frozen lung tissue samples (58 UME perinates; 17 reference perinates) using a commercially available kit (DNeasy, Qiagen) following the manufacturer's instructions. All samples were extracted in duplicate if there was sufficient sample available. Samples were tested for Brucella 16s rRNA DNA using a semi-quantitative real-time PCR with standard reagents (Gene Expression Master Mix, Applied Biosytems) and a minor groove binding probe that cross-reacts with known terrestrial and marine Brucella species (University of Illinois, Zoological Pathology Program Molecular Diagnostic Laboratory). Negative (sterile water substituted for DNA extract), extraction negative (extracted in parallel with samples using sterile water instead of tissue), and positive (clinical B. ceti isolate from a bottlenose dolphin) controls were included in each set of reactions. All reactions also included an internal positive control (Applied Biosystems TaqMan Exogenous Internal Positive Control). Threshold cycle $\left(C_{t}\right)$ for a positive sample was set at 35 cycles while samples that amplified between 35 and 40 cycles were considered equivocal. Presence 
of Brucella spp. DNA was confirmed in all equivocal samples by PCR amplification and sequencing of a 135 bp fragment of the Brucella 16SrRNA gene as well as a $\sim 750 \mathrm{bp}$ fragment of the outer membrane protein (omp2a) gene.

For positive real-time PCR samples, sequencing of the entire omp 2 gene was attempted using primers $2.33,2.50,2.51$ and 2.57 according to published protocols (Ficht et al. 1996). Two additional sequencing primers Bru3R 5'-CAG AAA TGA ACA TCA AGA GCC T-3' and Bru1F 5'-CCT CAA TTG TCG ATC CGC CT-3' were used in some cases for greater coverage. Nucleotide sequences were determined on an automated sequencer (Applied Biosystems 3730XL), and both strands were sequenced. Forward and reverse sequences were aligned to resolve ambiguous bases using Sequencher 5.0 software (GeneCodes). Sequences were compared to both known species of Brucella in GenBank and to each other using both a 2800 and $940 \mathrm{bp}$ region after trimming to the shortest sequence. Sequences were aligned using Clustal W, and evolutionary history was inferred by using the maximum likelihood method based on the Tamura-Nei model using MEGA version 6 (Tamura et al. 2013). Initial tree(s) for the heuristic search were obtained automatically by applying neighbor-join and BioNJ algorithms to a matrix of pairwise distances estimated using the maximum composite likelihood (MCL) approach and then selecting the topology with superior log likelihood value. Codon positions included were $1 \mathrm{st}+2 \mathrm{nd}$ $+3 \mathrm{rd}+$ Noncoding. All positions containing gaps and missing data were eliminated. There were a total of 2621 (for $2800 \mathrm{bp}$ fragment) and 749 (for $940 \mathrm{bp}$ fragment) positions in the final dataset.

\section{Microbiology}

Isolation of Brucella bacteria from UME perinate lung tissue $(\mathrm{n}=29)$ was performed by conventional methods (Alton et al. 1988) with minimal modifications. Briefly, each tissue was dipped in $95 \%$ ethanol and flamed, then homogenized with an equal volume of phosphate-buffered saline. This suspension was then swabbed onto non-selective and selective agars including trypticase soy agar with $5 \%$ serum, Columbia agar, trypticase soy agar with $5 \%$ serum and antibiotics, trypticase soy agar with $5 \%$ serum, antibiotics and ethyl-violet, Ewalt's media, and Farrell's media with $5 \%$ serum. Agar plates were incubated at $37^{\circ} \mathrm{C}$ and $10 \% \mathrm{CO}_{2}$ for a minimum of $15 \mathrm{~d}$, with observations typically at 5, 10 and $15 \mathrm{~d}$.

\section{Morbillivirus PCR assay}

Lung tissue from perinatal dolphins $(\mathrm{n}=11)$ was tested for morbillivirus using PCR. RNA extraction was conducted on tissues using RNeasy (Qiagen), on $0.5 \mathrm{~g}$ of tissue macerate, following the manufacturer's instructions. PCR was carried out by conventional semi-nested retrotranscriptase polymerase chain reaction (RT-PCR), which amplifies a $300 \mathrm{bp}$ within a conserved region in the phosphoprotein gene (P gene) (Sierra et al. 2014). Two negative controls (extraction and amplification) and an amplification positive control were used. PCR products were electrophoresed in $2 \%$ agarose gels and stained with ethidium bromide. A single band was present in all positive samples.

\section{Marine biotoxin analysis}

Testing for saxitoxin $(n=7)$, brevetoxin $(n=10)$, domoic acid $(n=13)$, okadaic acid $(n=8)$, and other diarrhetic shellfish poisoning toxins (DSP) $(n=4)$ was performed primarily on fecal samples using previously published methods (Fire et al. 2011). Brevetoxin (PbTx) was detected using a direct enzyme-linked immunosorbent assay (ELISA) method according to Maucher et al. (2007) and Fire et al. (2011), receptor binding assay methods (RBA) according to Twiner et al. (2011) and Van Dolah et al. (1994), and/or liquid chromatography-mass spectrometry (LC-MS) methods according to Fire et al. (2008). Samples were analyzed for the presence of domoic acid by tandem mass spectrometry coupled with LC-MS/MS (Wang et al. 2012). Analysis of the DSP toxins (okadaic acid $[\mathrm{OA}]$, dinophysistoxins [DTX-1 and DTX-2], and pectenotoxin-2 [PTX-2] followed methods previously described in Fire et al. (2011). Saxitoxin analysis was conducted using both RBA and LC-MS (Fire et al. 2012).

\section{RESULTS}

\section{Stranded GoM perinate dolphin demographics}

Of 769 reported dolphin strandings that had a reported total body length during the UME in Louisiana, Mississippi, and Alabama from January 2010 through December 2013, 171 (22\%) had a body length $<115 \mathrm{~cm}$. The mean and median lengths of perinates were $97 \pm 11$ and $97 \mathrm{~cm}$ (range 56 to $114 \mathrm{~cm})$, respectively. Forty-nine percent of the peri- 
nates were male, $38 \%$ were female, and in $14 \%$ sex was undetermined. Among 165 perinate dolphins with known carcass conditions at the time of initial observation, 1 was alive, 19 (12\%) were fresh, 114 (69\%) were moderately decomposed, 29 (18\%) were severely decomposed, and $2(1 \%)$ were mummified. UME perinatal dolphin strandings by year were 2010 ( $\mathrm{n}=27,16 \%), 2011(\mathrm{n}=77,45 \%), 2012(\mathrm{n}=24,14 \%)$, and 2013 ( $\mathrm{n}=43,25 \%)$ and by state were Louisiana ( $\mathrm{n}=47,27 \%)$, Mississippi $(\mathrm{n}=85,50 \%$ ), and Alabama ( $\mathrm{n}=39,23 \%)$.

As is typical for the northern GoM, the majority of perinatal dolphin strandings occurred during January through April in each year of this UME investigation (Fig. 2). During this timeframe, the highest number of perinate strandings occurred during 2011 in Mississippi and Alabama (Fig. 2). In addition to higher numbers of perinatal strandings, compared to state-specific baseline stranding data (January through April, 2000-2005) the prevalence of perinates among all stranded dolphins was significantly higher during 2011 in Mississippi and Alabama, and in 2012 in Alabama (Table 1). Body lengths of perinatal dolphins that stranded in Alabama and Mississippi during 2011 ( $\mathrm{n}=60,94 \pm 9 \mathrm{~cm}$ ) were shorter than stranded perinates from Louisiana during the same year $(\mathrm{n}=$ $17,104 \pm 8 \mathrm{~cm})(\mathrm{p}=0.0005)$.

\section{Gross UME perinate dolphin characteristics}

Perinatal characteristics were evaluated in a subset of dolphins, and not all characteristics were investigated in each individual. Thus, prevalence of each characteristic is scored only for those dolphins in which it was reported. The most common gross features reported for perinatal dolphins were fetal folds $(100 \%)$, open ductus arteriosus $(100 \%)$, caudal blowhole dent $(97 \%)$, creased dorsal fin (93\%), hair follicles (91\%), and a folded dorsal fin (88\%) (Table 2).

\section{Histologic evaluations - case-reference study}

Histologic evaluations were conducted on 69 UME perinatal dolphins for which at least lung was available for evaluation that stranded in Louisiana ( $\mathrm{n}=21$, $30 \%)$, Mississippi ( $\mathrm{n}=37,54 \%)$, and Alabama ( $\mathrm{n}=$ 11, 16\%) from March 2010 through June 2013. Perinatal dolphins were evaluated that stranded in 2010

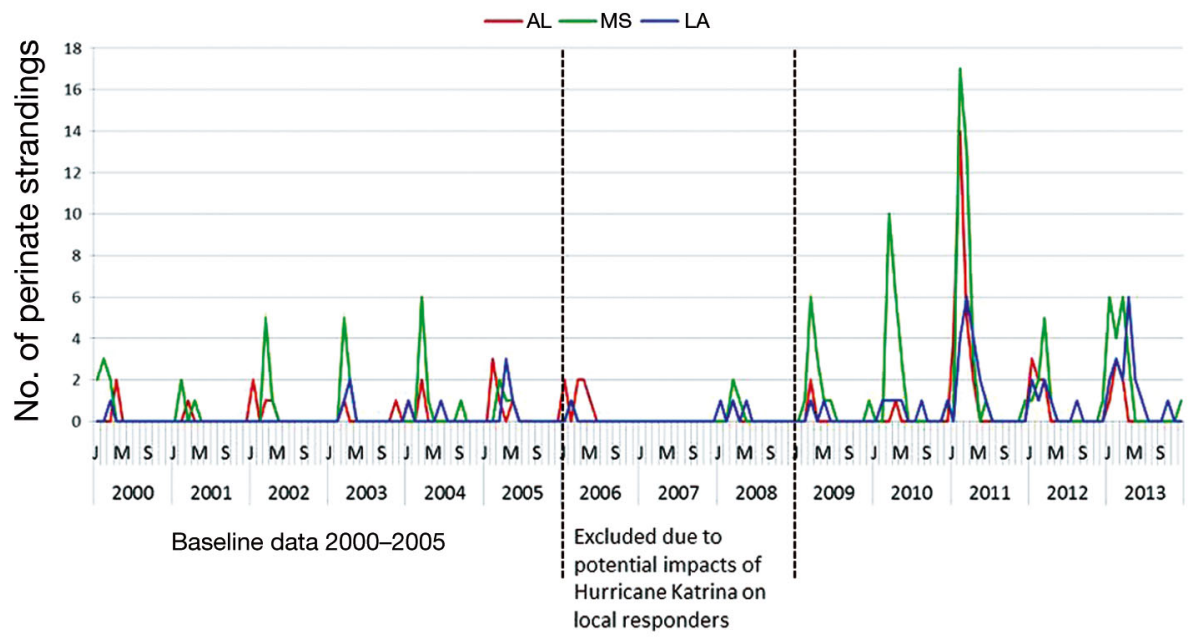

Fig. 2. Total numbers of stranded perinatal common bottlenose dolphins Tursiops truncatus per month in Alabama (AL), Mississippi (MS), and Louisiana (LA) for reference years (2000-2005 and 2009) and unusual mortality event years (2010-2013)

Table 1. Comparisons of the prevalence of perinates (body length $<115 \mathrm{~cm}$ ) among total number of bottlenose dolphins Tursiops truncatus stranded during January-April by state and year, 2009-2013 compared to the baseline reference period, 2000-2005. ${ }^{1} \mathrm{p}=0.055,{ }^{2} \mathrm{p}=0.001(\mathrm{OR}=3.2),{ }^{3} \mathrm{p}<0.0001(\mathrm{OR}=12.3),{ }^{4} \mathrm{p}=0.04,{ }^{5} \mathrm{p}=0.054,{ }^{*} \mathrm{p}<0.05$. OR: odds ratio

\begin{tabular}{|c|c|c|c|c|c|c|}
\hline \multirow{2}{*}{ Gulf state } & \multicolumn{6}{|c|}{ — Prevalence of perinatal strandings (\%) } \\
\hline & Baseline (2000-2005) & 2009 & 2010 & 2011 & 2012 & 2013 \\
\hline Louisiana & 8/52 (15) & $1 / 9(11)$ & $3 / 42(7)$ & 14/76 (18) & 6/37 (16) & 13/76 (17) \\
\hline Mississippi & $33 / 90(37)$ & $10 / 16(63)^{1}$ & $16 / 31(52)$ & $33 / 51(65)^{2, *}$ & $9 / 21(43)$ & $19 / 34(56)^{5}$ \\
\hline Alabama & $15 / 52(29)$ & $2 / 4(50)$ & $1 / 11(9)$ & $25 / 30(83)^{3, *}$ & $7 / 11(64)^{4, *}$ & $6 / 15(40)$ \\
\hline
\end{tabular}


Table 2. Prevalence of gross perinatal characteristics noted during necropsy of stranded unusual mortality event (UME) perinatal $(<115 \mathrm{~cm})$ bottlenose dolphins Tursiops truncatus. Denominators included dolphins in which the characteristic was assessed and that had tissues in adequate condition to evaluate

\begin{tabular}{|lcc|}
\hline Gross perinatal characteristic & $\begin{array}{c}\text { No. (\%) of perinates } \\
\text { with characteristic } \\
\text { present }\end{array}$ & $\begin{array}{c}\text { Mean } \pm \text { SD } \\
\text { body length } \\
(\mathrm{cm})\end{array}$ \\
\hline Fetal folds & $44 / 44(100)$ & $98 \pm 10$ \\
Open ductus arteriosus & $22 / 22(100)$ & $100 \pm 9$ \\
Caudal blowhole dent & $39 / 40(97)$ & $98 \pm 10$ \\
Creased dorsal fin & $38 / 41(93)$ & $98 \pm 9$ \\
Hair follicles & $39 / 43(91)$ & $100 \pm 9$ \\
Folded dorsal fin & $42 / 48(88)$ & $97 \pm 9$ \\
Nuchal dent & $33 / 39(85)$ & $97 \pm 10$ \\
Lingual papillae & $27 / 32(84)$ & $99 \pm 9$ \\
Open or attached umbilicus & $15 / 19(79)$ & $99 \pm 8$ \\
Rostral hairs & $29 / 42(69)$ & $101 \pm 7$ \\
Meconium & $20 / 30(67)$ & $98 \pm 9$ \\
Pulmonary atelectasis & $26 / 44(59)$ & $93 \pm 14$ \\
Maxilla teeth erupted & $10 / 41(24)$ & 6014 \\
Mandibular teeth erupted & $6 / 45(13)$ & \\
\hline
\end{tabular}

atelectasis and fetal distress was highest in 2012, although lesion prevalence was, in general, similar during all years of this investigation (Fig. 3). A total of 60 (87\%) UME perinatal dolphins had increased numbers of amniotic squamous cells and/ or meconium within alveoli or bronchioles consistent with fetal distress (Fig. 4B). Aspirated meconium was globular and golden brown to yellow depending on degree of autolysis (Fig. 4B). Among perinates with fetal distress, severity was mild $(\mathrm{n}=10$, $17 \%)$, moderate $(n=32,53 \%)$, and severe $(n=18,30 \%)$.

In forty-five $(65 \%)$ of the UME perinatal dolphins, pneumonia was present in combination with atelectasis and/or fetal distress but not associated with lungworm infection, warranting the sub-classification of 'in
( $\mathrm{n}=5,7 \%), 2011(\mathrm{n}=25,36 \%), 2012$ ( $\mathrm{n}=15,22 \%)$, and 2013 ( $\mathrm{n}=24,35 \%$ ). UME perinate carcass conditions were fresh dead ( $\mathrm{n}=14,20 \%)$, moderately decomposed ( $\mathrm{n}=49,71 \%$ ), or in a state of advanced decomposition ( $\mathrm{n}=6,9 \%$ ). The demographics of UME perinates evaluated histologically were comparable to overall UME perinate demographics. Twenty-six reference perinatal dolphins included in this study stranded outside of the UME geographic area in South Carolina ( $\mathrm{n}=17,65 \%$ ) between 1996 and 2012 and in Florida ( $\mathrm{n}=$ 9, $35 \%$ ) between 2006 and 2009. Carcass conditions of reference perinates were fresh dead $(\mathrm{n}=19,73 \%)$ and moderately decomposed ( $\mathrm{n}=7,27 \%$ ).

Pneumonia, or inflammation within the lung, was common in UME perinates. When comparing UME and reference perinates, there were no differences in sex, the prevalence of histologically abnormal lungs, or the prevalence of pneumonia in general. UME perinates, however, were more likely to have atelectasis, fetal distress (OR = 18), and in utero infection (pneumonia) not due to lungworm infection ( $\mathrm{OR}=8)$, compared to reference perinates (Table 3, Fig. 3). The prevalence of these 3 lesions was not different among perinates that sippi and Alabama (Table 4). Among UME perinates, the prevalence of stranded in Louisiana versus Missis- utero infection other than lungworm infection'. This prevalence was higher than observed in reference perinates $(19 \%, p=0.0001)$. In cases with pneumonia, the severity of the inflammation was graded subjectively as mild (37\%), moderate (43\%), and severe (20\%). In perinatal dolphins with in utero pneumonia not associated with lungworm infection, alveolar spaces multifocally contained macrophages, eosinophilic debris, and lesser numbers of necrotic and viable neutrophils and lymphocytes (Fig. 4C). In most cases, inflammatory cells within airways surrounded amniotic squamous cells (Fig. 4D). Multifocally, alveolar septae were thickened and contained similar inflammatory cells (Fig. 4C). In some cases, there was advanced autolysis, which hindered evaluation of epithelial damage and determination of inflamma-
Table 3. Comparisons of demographics and the prevalence of lesions between perinatal common bottlenose dolphins Tursiops truncatus from the ongoing unusual mortality event ( $\mathrm{UME}, \mathrm{n}=69)$ and a reference group $(\mathrm{n}=26)$

\begin{tabular}{|lccc|}
\hline Descriptor & UME (\%) & Reference (\%) & $\mathrm{p}$ \\
\hline Female $^{\mathrm{a}}$ & $34 / 69(49)$ & $10 / 26(38)$ & 0.31 \\
Mean body length \pm SD (cm) & $100 \pm 9$ & $103 \pm 10$ & 0.10 \\
Abnormal lungs & $67(97)$ & $23(88)$ & 0.12 \\
Full or partial atelectasis & $61(88)$ & $4(15)$ & $<0.0001$ \\
Fetal distress & $60(87)$ & $7(27)$ & $<0.0001$ \\
In utero infection, not lungworm & $45(65)$ & $5(19)$ & $<0.0001$ \\
Pneumonia & $49(71)$ & $15(58)$ & 0.22 \\
Brucella PCR-positive lung $^{\text {a }}$ & $32 / 58(55)$ & $4 / 17(24)$ & 0.02 \\
a Sex and Brucella PCR data were not available for all dolphins & \\
\hline
\end{tabular}




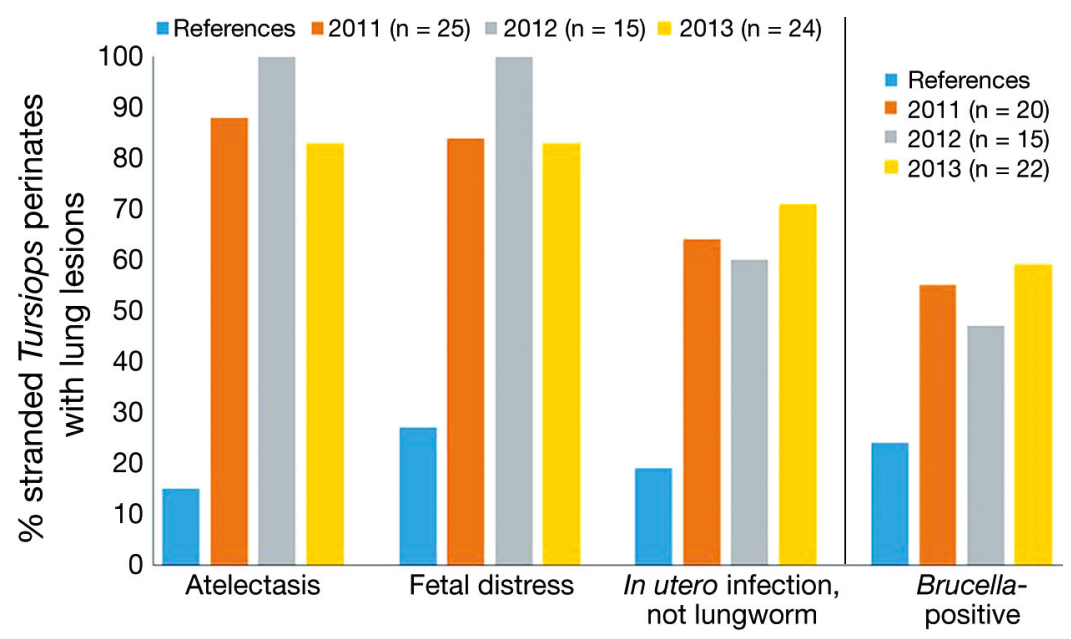

Fig. 3. Percent of stranded, perinatal common bottlenose dolphins Tursiops truncatus with key pulmonary lesions during the unusual mortality event (UME) in Louisiana, Mississippi, and Alabama by year (2011-2013). Reference perinatal group: dolphins that stranded along coastal Gulf Florida and South Carolina outside of the UME timeframe and/or location $(n=26)$. Due to the low number of perinates evaluated during 2010 ( $n=5$ ), percentages for 2010 are not provided in this graph; total numbers for perinates evaluated during 2010: atelectasis $=5 / 5$, fetal distress $=4 / 5$, in utero infection, not lungworm $(\mathrm{n}=3 / 5)$, and Brucella-positive ( $\mathrm{n}=1 / 1)$

Table 4. Comparisons of histologic lung lesions between Gulf of Mexico unusual mortality event (UME) bottlenose dolphin Tursiops truncatus perinatal cases that stranded in Mississippi and Alabama (MS \& AL, n = 48) vs. Louisiana (LA, $\mathrm{n}=21$ ), 2010-2013

\begin{tabular}{|c|c|c|c|}
\hline Descriptor & MS \& AL (\%) & LA $(\%)$ & $\mathrm{p}$ \\
\hline Mean body length $\pm \mathrm{SD}(\mathrm{cm})$ & $98 \pm 9$ & $103 \pm 9$ & 0.02 \\
\hline Percent female & $21 / 48(44)$ & $13 / 21(62)$ & 0.157 \\
\hline Abnormal lungs & $47(98)$ & $20(95)$ & 0.52 \\
\hline Full or partial atelectasis & $43(90)$ & $18(86)$ & 0.69 \\
\hline Fetal distress & $44(92)$ & $16(76)$ & 0.09 \\
\hline In utero infection, not lungworm & $34(71)$ & $11(52)$ & 0.14 \\
\hline Pneumonia & $37(77)$ & $12(57)$ & 0.10 \\
\hline Brucella PCR-positive lung ${ }^{a}$ & $25 / 41(61)$ & $7 / 17(41)$ & 0.17 \\
\hline
\end{tabular}

tory cell type; increased cellularity indicative of pneumonia, however, was discernible. In many cases, post mortem bacterial overgrowth made identification of potential lesion-associated bacteria impossible. Ninety-four percent of all UME cases with pneumonia had partial or complete atelectasis and $97 \%$ had concurrent fetal distress with aspiration of amniotic squamous cells and in some cases meconium. All of the UME perinates with pneumonia that lacked fetal distress had lungworm infection.

In UME dolphins in which lung tissue was PCRpositive for Brucella, complete atelectasis, moderate to severe fetal distress, and moderate to severe inflammation were common (Table 5). The majority of the UME perinatal dolphins positive for Brucella sp. DNA had in utero inflammation not associated with lungworm infection (31/32, 97\%). Similar inflammation was noted in all 4 of the reference perinatal dolphins positive for Brucella sp. DNA in the lungs and 3 of 4 Brucella sp.-positive reference dolphins also had atelectasis and fetal distress. Of the UME perinates with pneumonia that were tested for Brucella via PCR, 31 of $45(69 \%)$ had Brucella sp. DNA amplified from the lung. In $39 \%$ of PCR-positive cases, alveolar septae contained nodular to follicle-like accumulations of lymphocytes (Fig. 4C). Of these PCR-positive cases with lymphoid follicle formation, most (8/14, $57 \%$ ) had severe pneumonia. Lymphoid follicles were not noted in any of the cases of fetal pneumonia in either UME or reference dolphins which Brucella PCR on lung was negative. Only 2 UME and reference PCR-positive cases lacked evidence of pneumonia. Of the UME and reference cases in which Brucella PCR was negative, only 2 had severe pneumonia; one case was associated with dystocia, and one case had a severe lungworm infection. Two UME perinatal dolphins with Brucella sp. infection had mild perivascular dermatitis, and one of these perinatal dolphins also had mild neutrophilic myocarditis.

Five UME perinates had multiple clusters of metastrongyle parasites within bronchi and bronchioles. Many parasites were adults and had numerous larvae within uteri. In 3 of the perinate UME dolphins with lungworm infection, inflammation was mild with small numbers of neutrophils and eosinophils surrounding parasites. Lungworms in one UME perinatal dolphin were not associated with inflammation. In the fifth UME perinatal dolphin with lungworms, parasites were surrounded by necrotic debris, large numbers of macrophages, and neutrophils, and there was granuloma formation around adult and larval parasites. These parasites were morphologically consistent with the dolphin lungworm Halocercus sp. Similar lung- 

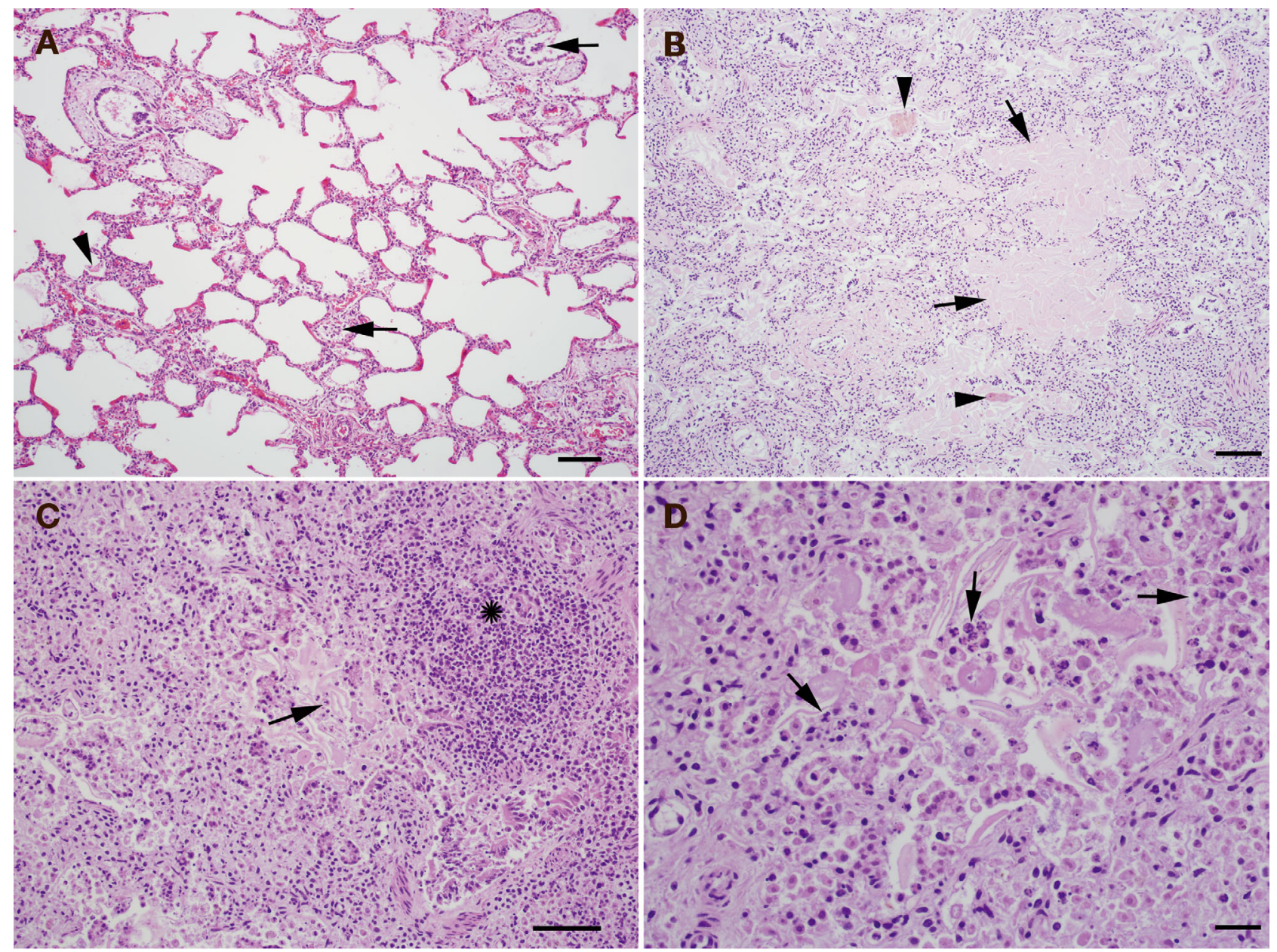

Fig. 4. Photomicrographs of perinate common bottlenose dolphin Tursiops truncatus lungs. (A) Normal lung from a perinate dolphin that stranded along the west coast of Florida; airways contain only a few amniotic squamous cells (arrowhead) and small numbers of artifactually sloughed epithelial cells (arrows). Scale bar $=100 \mu \mathrm{m}$. (B) Atelectic lung from a dolphin that stranded in Louisiana with large numbers of aspirated amniotic squamous cells (arrows) and globular golden brown meconium (arrowheads) consistent with fetal distress. Scale bar $=100 \mu \mathrm{m}$. (C) Lung from a dolphin that stranded in Louisiana with fetal distress and pneumonia due to Brucella sp. in utero infection. Note the large number of inflammatory cells within the airways and septae (arrow) and the follicle-like accumulation of lymphocytes (asterisk). Scale bar $=100 \mu$ m. (D) Higher power magnification image of lung from a dolphin in Louisiana with fetal distress and pneumonia due to Brucella sp. in utero infection. There are inflammatory cells including neutrophils (arrows) surrounding amniotic squamous cells. Scale bar $=50 \mu \mathrm{m}$

worm infections and associated inflammation were noted in $6(23 \%)$ of the reference perinatal dolphins.

\section{Immunohistochemistry}

Three of the 5 perinates positive for Brucella via PCR had positive $B$. abortus antigen staining using immunohistochemistry within inflammatory cells and mixed with debris and amniotic squamous cells within alveolar spaces (Fig. 5). One perinate negative for Brucella via PCR was also negative using immunohistochemistry.

\section{Brucella PCR}

Among the 69 UME perinatal dolphins in which tissues were submitted for histologic evaluation, 58 $(84 \%)$ had available frozen lung samples which were tested by PCR for the presence of Brucella DNA, and 32/58 (55\%) were positive for Brucella sp. DNA. The prevalence of Brucella in reference perinatal dolphins was $4 / 17(24 \%)(p=0.02)$ (Table 3). Prevalence of UME perinatal dolphins positive for Brucella was similar from 2011 to 2013. When UME geographic areas were compared separately to reference perinates $(24 \%)$, perinates that stranded in Mississippi 
Table 5. Prevalence of histologic pulmonary lesions in unusual mortality event (UME) $(\mathrm{n}=32)$ and reference $(\mathrm{n}=4)$ perinatal bottlenose dolphins Tursiops truncatus in which lung was positive via PCR for Brucella sp.

\begin{tabular}{|lc|}
\hline Lesions & $\begin{array}{c}\text { No. of perinates }(\%) \\
(\mathrm{n}=36)\end{array}$ \\
\hline Complete atelectasis & $26 / 36(72)$ \\
Partial atelectasis & $7 / 36(19)$ \\
Fetal distress & $34 / 36(94)$ \\
Mild & $1 / 34(3)$ \\
Moderate & $20 / 34(59)$ \\
Severe & $13 / 34(38)$ \\
Inflammation & $34 / 36(94)$ \\
Mild & $9 / 34(26)$ \\
Moderate & $15 / 34(44)$ \\
Severe & $10 / 34(29)$ \\
Lymphoid follicle formation & $14 / 36(39)$ \\
\end{tabular}

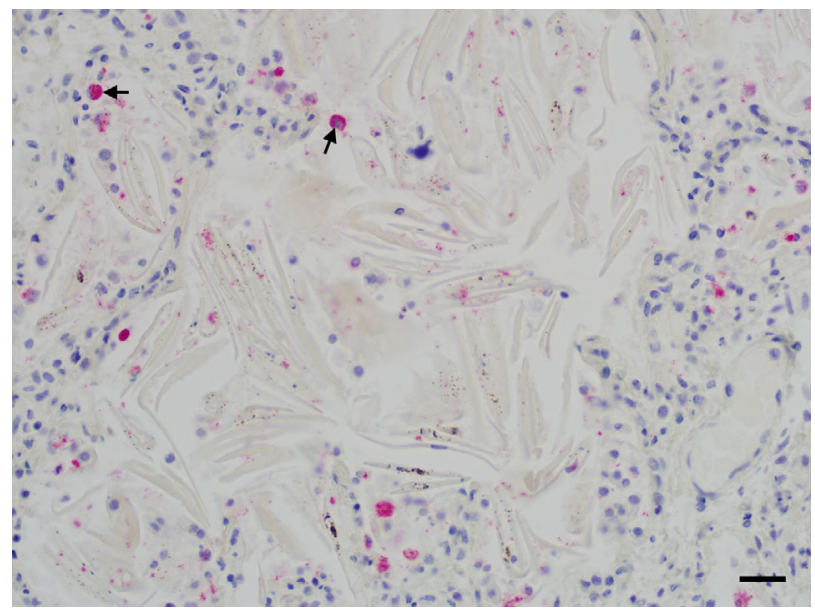

Fig. 5. Photomicrograph of lung from a perinate dolphin stranding in Louisiana stained with a polyclonal antibody against Brucella abortus. Note the positive pink staining scattered among amniotic squamous cells within alveolar spaces and within the cytoplasm of inflammatory cells (arrows). Scale bar $=20 \mu \mathrm{m}$

and Alabama (61\%) had a significantly higher prevalence of Brucella PCR-positive lung ( $p=0.01)$. In contrast, the proportion of perinates that were Brucella PCR-positive was similar when comparing Louisiana $(41 \%)$ and reference perinates $(p=0.46)$.

DNA was of sufficient quality from lung tissue from 12 Brucella-positive UME perinatal dolphins and one reference perinate (MML0408) to obtain a complete (2800 bp) omp2 gene sequence (Fig. 6) and in an additional 5 positive UME perinates to obtain at least $940 \mathrm{bp}$ of readable sequence (Fig. 7) (GenBank accession numbers KT364234-KT364251). An additional 9 UME perinatal dolphins were positive by Brucella PCR, but sequence confirmation was limited to a $120 \mathrm{bp}$ fragment of the 16s rRNA gene. The omp2 sequences were compared with those of known Brucella reference strains as well as samples from marine mammals at other sites (Figs. $6 \&$ \&). Trees with the highest log likelihood (-7548.2652 for 2800 bp sequences, Fig. 6 ; and -3347.1742 for $940 \mathrm{bp}$ sequences, Fig. 7) are shown. Findings from analysis of the omp2 gene suggest the presence of at least 2 and possibly 3 sequence variants of Brucella spp. within the submitted tissues from UME perinates.

\section{Microbiology}

Brucella ceti was cultured from lung tissue in 3/29 $(10.3 \%)$ UME perinates, all 3 of which were in fresh (Code 2) post mortem condition at the time of sampling. The 3 culture-positive UME perinates were also positive for Brucella sp. via PCR. Twenty-six UME perinates positive for Brucella via PCR were negative on culture, and 22/26 culture-negative UME perinates had moderate (Code 3) or advanced (Code 4) post mortem decomposition at the time of sampling. Mixed growth of multiple bacterial species was found in multiple tissues (e.g. brain, lung, and liver) of 4 Code 2 UME perinates consistent with post mortem bacterial overgrowth.

\section{Morbillivirus PCR and marine biotoxin evaluation}

All UME perinates were tested for morbillivirus using PCR were negative. Perinate UME dolphins tested for marine biotoxins were negative for domoic acid $(\mathrm{n}=13)$, saxitoxin $(\mathrm{n}=7)$ and DSP toxins (OA, $\mathrm{n}=8$; other DSP toxins, $\mathrm{n}=4$ ). Of the 10 perinates tested for brevetoxin, $3(30 \%)$ were positive at low levels by ELISA (up to $16 \mathrm{ng} \mathrm{g}^{-1}$ ) but were below the detection limit or present in trace quantities by LCMS. Brevetoxin results were available for 4 reference perinates, one of which was positive by RBA (188 ng $\mathrm{g}^{-1}$ ) and LC-MS (15 $\left.\mathrm{ng} \mathrm{g}^{-1}\right)$.

\section{DISCUSSION}

In the current study, distinct demographic characteristics and pathologic lesions were identified in bottlenose dolphin perinates that stranded between 2010 and 2013 as part of the northern GoM UME. There was also a significant increase in the number and prevalence of stranded perinates in Mississippi and Alabama during 2011, and these perinates were 


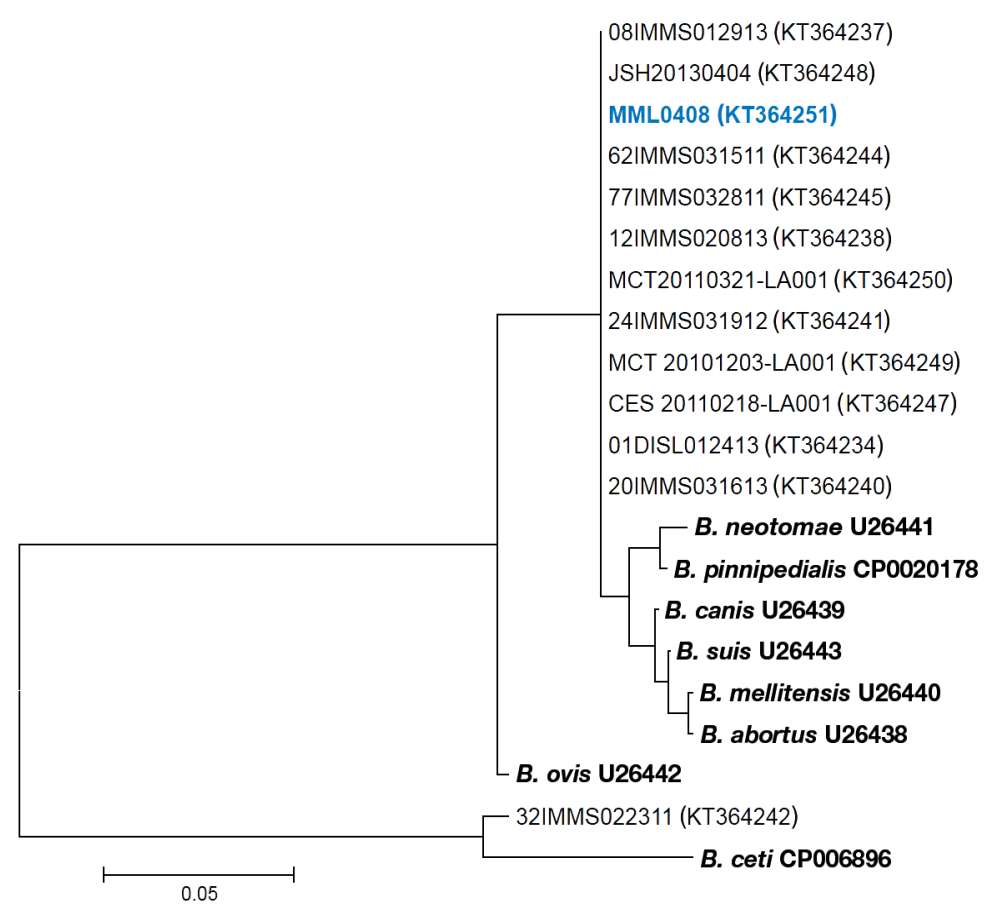

Fig. 6. Phylogenetic comparison of Brucella omp2 (2a and 2b) gene sequences (2800 bp) among terrestrial and marine Brucellas including 12 animals from the Gulf of Mexico. For other marine mammal and terrestrial strains, the number after the species name is the GenBank accession number. B. ceti (CP006896) was isolated from a striped dolphin Stenella coeruloeoalba. All Gulf of Mexico dolphins are listed by their field identification number with GenBank accession number in brackets. MML0408 highlighted in blue is a reference, non-unusual mortality event (UME) dolphin that stranded along the western coast of Florida in 2004. Maximum likelihood phylogeny using Tamura-Nei substitution method in MEGA 6

significantly smaller than those that stranded during previous years and in other geographic locations. The stranding of shorter perinates may indicate that more pre-term dolphins died in utero and were aborted during 2011 in Mississippi and Alabama. Grossly observed characteristics were similar to those reported previously in fetal or neonatal dolphins (e.g. patent ductus arteriosus), further indicating that most perinates examined were preterm aborted fetuses or very young newborns (McBride \& Kritzler 1951, Cockcroft \& Ross 1990, Dearolf et al. 2000).

Atelectasis, fetal distress, and in utero pneumonia not due to lungworm infection were commonly noted in UME perinates. The high prevalence of partial or complete atelectasis detected in UME perinates indicates that most perinates died in utero and were aborted or died shortly after birth and failed to completely inflate their lungs prior to death. Perinatal dolphins that stranded during the UME were 18 times more likely to have fetal distress compared to reference dolphins. Causes of in utero fetal distress include fetal hypoxia due to placental abnormalities (i.e. umbilical cord torsion) or infections that cause placental necrosis and reduce gaseous exchange, severe maternal anemia or malnutrition (through decreasing the oxygen carrying capacity of the blood), maternal hypoxia, and maternal shock (Keeling 2007). Fetal distress can also occur during the birthing process with dystocia or abnormally strong uterine contractions (Keeling 2007). Of these possible causes of in utero fetal distress, it is unlikely that population-wide increases in fetal distress were due to an epizootic of umbilical cord torsions or dystocias.

UME perinatal dolphins were also 8 times more likely to have in utero pneumonia not due to lungworm infection compared to reference perinates. Based on the distribution of inflammation within affected perinates, most pneumonias noted were consistent with in utero infection primarily arising from infection of the placenta, amniotic fluid or hematogenous spread (Gould 2007). In utero infection arising from infection of the amniotic fluid could occur through entry of microorganisms through an open cervix or systemic infections that localize to the placenta (Jeffery 2007).

As part of an investigation into the potential impact of the DWH oil spill, health assessments conducted during August 2011 on live non-perinatal dolphins within the UME region (Barataria Bay, Louisiana) demonstrated a high prevalence of advanced lung disease, blood values consistent with hypoadrenocortism or inflammation, poor body condition, and overall guarded to poor prognoses for survival (Schwacke et al. 2014). Corresponding to these changes noted in live dolphins, non-perinate dolphins dying in Louisiana, Mississippi, and Alabama from 2010-2012 had an increased prevalence of adrenal cortical atrophy and bacterial pneumonia (Venn-Watson et al. 2015b). Any of these abnormalities could have led to abortion in pregnant dolphins. Severe lung disease with or without bacterial infections in dolphin dams may have resulted in in utero infection through direct spread of bacteria to the placenta or to a fetal distress reaction due to maternal hypoxia (Keeling 2007). Additionally, pregnant sheep with hypoadrenocorticism are susceptible to late-term pregnancy losses 


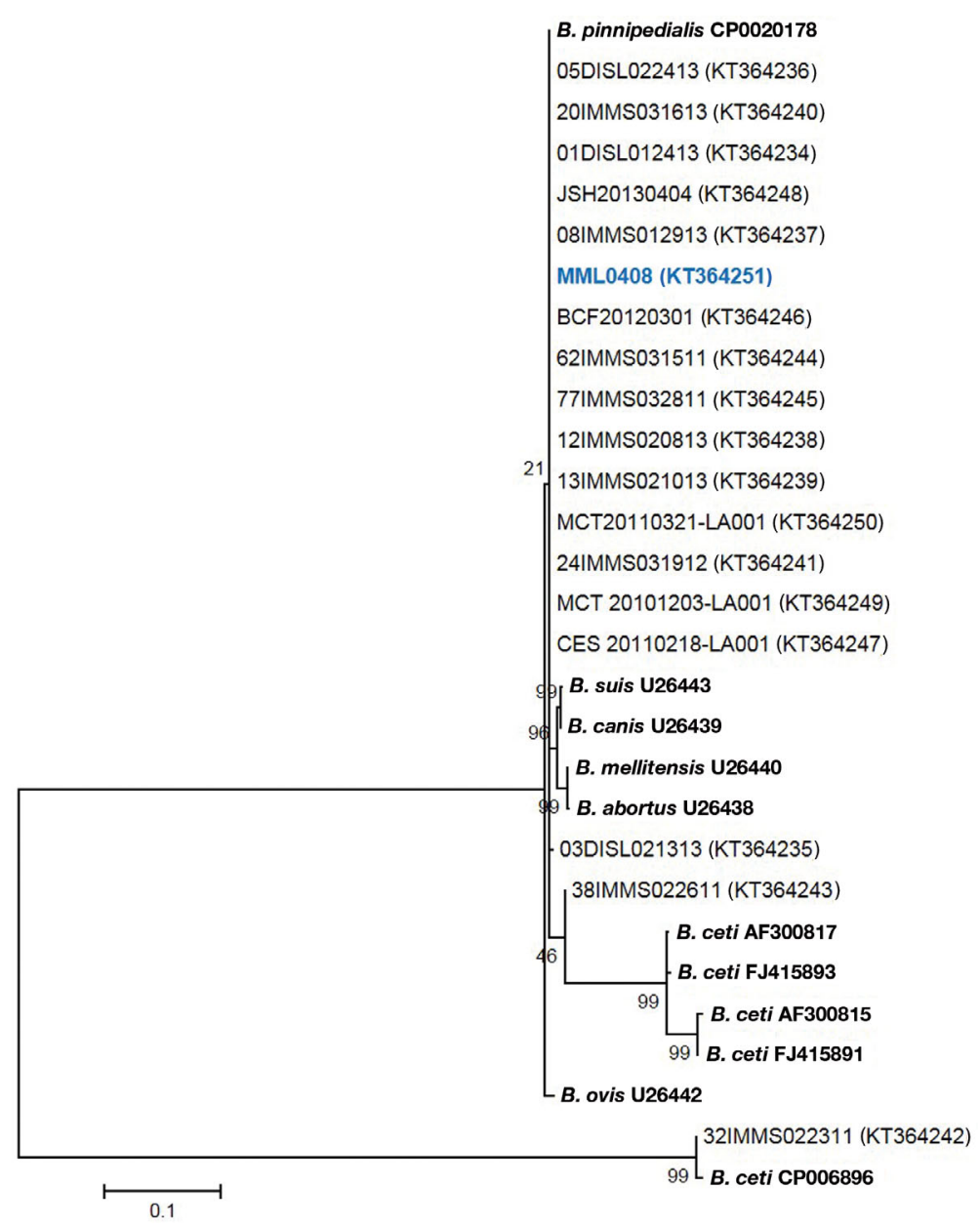

Fig. 7. Phylogenetic comparison of Brucella omp2a partial gene sequences $(940 \mathrm{bp})$ among terrestrial and marine Brucellas including 17 animals from the Gulf of Mexico. For other marine mammal and terrestrial strains, the number after the species name is the GenBank accession number. B. ceti reference strains were isolated from striped dolphins (Stenella coeruloeoalba; CP006896, FJ415891), common dolphins (Delphinus delphis; AF388815, FJ415893) and a porpoise (Phocoena phocoena; AF300817). All Gulf dolphins are listed by their field identification number with GenBank accession number in brackets. MML0408 highlighted in blue is a reference, non-unusual mortality event (UME) dolphin that stranded along the western coast of Florida in 2004. Maximum-likelihood phylogeny using Tamura-Nei substitution method in MEGA 6. Percentage of trees in which the associated taxa clustered together shown next to the branches

(Keller-Wood et al. 1998). Thus, there is evidence that the high prevalence of in utero fetal distress, infection not due to lungworm, and late-term pregnancy losses or poor post-partum survival of UME perinates may be directly related to the poor health of dolphin dams following the DWH oil spill.

While the specific cause(s) of in utero pneumonia was not apparent in all perinates, interestingly, Brucella infection was identified by PCR in over half of the UME perinates tested and a quarter of the reference perinates. The morphology of the lesions among Brucella sp.-positive UME and reference perinates was similar, including the presence of folliclelike aggregates of lymphocytes within alveolar septae. Brucella infection could also be confirmed via culture and immunohistochemistry in some cases. Culture of Brucella was hampered in many cases by post mortem decomposition, overgrowth of post mortem bacteria contaminating culture plates, and tissue quantity. In utero Brucella sp. infection should be a top differential in dolphin perinates with severe pneumonia and concurrent fetal distress, especially if lymphoid follicle formation is noted. Morphologically similar bronchopneumonia has been reported in bison and bovine fetuses aborted due to $B$. abortus infection (Rhyan et al. 2001, Xavier et al. 2009).

While brucellosis has been associated with late-term abortions in cetaceans and some terrestrial species, it has not been previously associated with perinatal dolphin mortality events (Davis et al. 1990, Samartino \& Enright 1993, Miller et al. 1999, Wanke 2004, Guzmán-Verri et al. 2012). In the current study, UME perinates that stranded in Mississippi and Alabama (but not Louisiana) were more likely to have brucellosis compared to the reference perinates. As such, many of the cases of fetal distress and pneumonia in Louisiana perinates, and at least some of the Mississippi and Alabama perinates were likely caused by other non-Brucella factors. Unfortunately, the baseline PCR-positive prevalence of Brucella in dolphins by stock in the northern GoM region is currently unknown, making it difficult to ascertain why geographic or stock differences in Brucella PCR prevalence were noted in this investigation. In bovine herds in which Brucella infection is endemic, incidence of infection can reach $20-30 \%$, which is similar to the percentage of PCR-positive reference dolphins (Schlafer \& Miller 2007). Brucella infections were not a major cause of death in non-perinate dolphins that died during the northern GoM UME from 2010 to 2012; however, studies of dolphins in managed care have shown that Brucella sp. infections that induce abortion may not 
necessarily cause mortality in the dam (Meegan et al. 2012, Venn-Watson et al. 2015b).

The high PCR prevalence of Brucella sp. infection identified in Mississippi and Alabama perinates could potentially have occurred due to increased host susceptibility to brucellosis in populations with endemic infections. Based on omp2 gene sequence analysis, it appears that multiple Brucella strains were present within stranded dolphins in the GoM. In addition, some of the strains detected in animals during the UME were similar to a strain amplified from a bottlenose dolphin perinate that stranded in 2004 along the central western coast of Florida (MML0408). These findings support that perinatal deaths were not due to a single novel Brucella type. Instead, other factors may have increased susceptibility to Brucella sp. infection and/or associated abortion.

The 2010 DWH oil spill, in which oil discharged from April 20 through July 15, reached the coastlines of Louisiana, Mississippi, and Alabama, (McNutt et al. 2012). During and following the oil spill, elevated levels of polycyclic aromatic hydrocarbons (PAHs) were detected in these coastal environments (Allan et al. 2012). Exposure to DWH oil spill-associated contaminants has been previously proposed as one of multiple potential contributing factors to the 2011 cluster of perinatal deaths in Mississippi and Alabama (Carmichael et al. 2012). Given that the high prevalence of brucellosis and greatest increases in perinatal strandings were not apparent until after the oil spill, there may have been oil-associated factors that led to an increase in failed pregnancies, one of which may have included altered maternal immune system function resulting in increases in illnesses.

Previous studies have identified associations between oil and hydrocarbon exposures, impacts on immune systems, and failed pregnancies in terrestrial species. Mink exposed to crude oil through ingestion had lower numbers of live born kits than unexposed control mink, and exposure has also been shown to cause significant perturbations in immune system function (Mazet et al. 2001, Schwartz et al. 2004). Additionally, women exposed to hydrocarbons during pregnancy have an increased risk of abortion (Xu et al. 1998, San Sebastian et al. 2002). Gestation length in bottlenose dolphins is approximately $380 \mathrm{~d}_{i}$ therefore, dolphin dams that aborted or lost late-term fetuses in early 2011 would have been in the earlier stages of pregnancy during the DWH oil spill in 2010 (Smith et al. 2013). Any late-term reproductive failure related to oil exposure would have occurred in late 2010 and beyond. Alterations in immune system function may play a role in either susceptibility to initial infection with Brucella sp. or persistence of infection. Protection against intracellular pathogens such as Brucella sp. requires an adequate cell-mediated immune response (Skendros \& Boura 2013). Brucella is also known to cause latent infections in which the bacteria persist within phagocytic cells in a dormant state and at a later time replicate and cause clinically significant recrudescent disease (Olsen \& Palmer 2014). People with chronic or re-lapsing brucellosis have been shown to have a reduced Th-1 immune response (Skendros \& Boura 2013). Exposure to oil spill-associated contaminants and immune system perturbations could have potentially led to an increase in non-Brucella infections affecting the placenta or to the moderate to severe lung disease and bacterial pneumonias identified in live and dead, non-perinatal dolphins during the UME (Schwacke et al. 2014, Venn-Watson et al. 2015b). Future investigations on immune function in GoM dolphins are needed to determine whether exposure to hydrocarbons during the DWH oil spill or other environmental stressors may have caused an increased susceptibility to infectious agents that affect the fetal-placental unit or other conditions leading to late term fetal loss.

This investigation further supports that dolphins can be infected by lungworms via transplacental transmission (Dailey et al. 1991, Fauquier et al. 2009). The significance of this very early lungworm infection is uncertain, although several perinates in this study had a significant inflammatory response to the parasites. It is possible, therefore, that parasitic pneumonia acquired transplacentally may contribute to morbidity and mortality in some perinatal and very young dolphin calves.

Only a few UME perinates had lesions identified outside of the respiratory system, and there was no evidence that either morbillivirus or biotoxins played a role in the perinate deaths. Since autolysis was substantial in many cases $(95 \%$ had moderate to advanced decomposition), lung was sometimes the only tissue available for histologic assessment, and in others post mortem artifact may have masked other tissue lesions. The perivascular dermatitis and myocarditis noted in several perinates that were PCRpositive for Brucella sp. may be a manifestation of bacteremia. Unfortunately, lung was often the only tissue available for PCR testing in this investigation, and post mortem condition precluded bacterial culture in most cases; therefore, future studies should aim to better characterize the distribution of Brucella sp. bacteria in aborted dolphin perinates. Another 
limitation of this investigation was the lack of baseline histopathologic and diagnostic test data in the GoM dolphins available for this study to review. Improvements in sampling and evaluations of perinatal mortalities across dolphin stocks in the future would improve our knowledge of what causes the expected annual increase in perinatal mortalities in the northern GoM including future trends in prevalence of brucellosis and strains of Brucella sp.

In summary, this study supports that perinatal dolphins throughout Louisiana, Mississippi, and Alabama were susceptible to fetal distress and in utero infections during the northern GoM UME. Pregnant dolphins from Alabama and Mississippi, especially during 2011, were susceptible to earlier fetal losses than had been reported in previous years and to Brucella-associated abortion. Importantly, this study demonstrates that the increased numbers of stranded perinates were not due to a single novel Brucella clade. There continues to be a need to understand why dolphins were particularly susceptible to lateterm fetal loss in this UME, including the potential contributing role of the DWH oil spill.

Acknowledgements. This work could not have been conducted without the efforts of the Marine Mammal Stranding Network, including additional personnel from those agencies working on the northern GoM UME: Louisiana Department of Wildlife and Fisheries (especially staff from the Fisheries Research Lab in Grand Isle), Audubon Aquarium of the Americas, Institute for Marine Mammal Studies, Dauphin Island Sea Lab, Emerald Coast Wildlife Refuge, and Gulf World Marine Park, particularly M. Brodsky, J. Hartley, M. Kelley, C. N. Seely, N. Wingers, M. Stolen, D. Boyd, B. MacLean, and S. Maillian. The authors acknowledge the northern GoM UME Investigative Team and the past and present members of the Working Group for Marine Mammal Unusual Mortality Events. We thank E. Stratton and L. Aichinger Dias for their integral roles in the perinate necropsy session. We thank B. Mase-Guthrie and E. Stratton for coordination of the SER Marine Mammal Stranding Network. We thank N. Ahmed and J. Landolfi for their integral work in completing the PCR assays and B. Thomsen for completion of immunohistochemistry. M. Broadwater is acknowledged for her assistance in biotoxin analysis. The biotoxin analysis was conducted through the National Centers for Coastal Ocean Science (NCCOS) Harmful Algal Bloom Analytical Response Team. C. Quance and S. RobbeAusterman from National Veterinary Services Laboratories, Animal and Plant Health Inspection Service are acknowledged for their work on Brucella culture. We thank the following individuals who helped review or otherwise contribute to portions of this manuscript: L. Engleby, S. Horton, L. Schwacke, C. Smith, Z. Wang, and F. Van Dolah. Funding for this investigation was provided in part by the NMFS UME contingency fund, NOAA Marine Mammal Health and Stranding Response Program and as part of the Deepwater Horizon oil spill Natural Resource Damage Assessment being conducted cooperatively between NOAA, other federal and state trustees and BP.

\section{LITERATURE CITED}

Allan SE, Smith BW, Anderson KA (2012) Impact of the Deepwater Horizon oil spill on bioavailable polycyclic aromatic hydrocarbons in the Gulf of Mexico coastal waters. Environ Sci Technol 46:2033-2039

Alton GG, Jones LM, Angus RD, Verger JM (1988) Techniques for the brucellosis laboratory. INRA Publications, Paris, p 34-61

> Carmichael RH, Graham WM, Aven A, Worthy G, Howden S (2012) Were multiple stressors a 'perfect storm' for northern Gulf of Mexico bottlenose dolphins (Tursiops truncatus) in 2011? PLoS ONE 7:e41155

Cassle SE, Jensen ED, Smith CR, Meegan JM and others (2013) Diagnosis and successful treatment of a lung abscess associated with Brucella species infection in a bottlenose dolphin (Tursiops truncatus). J Zoo Wildl Med 44:495-499

Cockcroft VG, Ross GJB 1990 Observations on the early development of a captive bottlenose dolphin calf. In: Leatherwood S, Reeves RR (eds) The bottlenose dolphin. Academic Press, San Diego, CA, p 461-478

> Dagleish MP, Barley J, Finlayson J, Reid RJ, Foster G (2008) Brucella ceti associated pathology in the testicle of a harbour porpoise (Phocoena phocoena). J Comp Pathol 139: $54-59$

> Dailey M, Walsh M, Odell D, Campbell T (1991) Evidence of prenatal infection in the bottlenose dolphin (Tursiops truncatus) with the lungworm Halocercus lagenorhynchi (Nematoda: Pseudaliidae). J Wildl Dis 27:164-165

Davis DS, Templeton JW, Ficht TA, Williams JD, Kopec JD, Adams LG (1990) Brucella abortus in captive bison. I. Serology, bacteriology, pathogenesis, and transmission to cattle. J Wildl Dis 26:360-371

> Davison NJ, Barnett JE, Perrett LL, Dawson CE, Perkins MW, Deaville RC, Jepson PD (2013) Meningoencephalitis and arthritis associated with Brucella ceti in a shortbeaked common dolphin (Delphinus delphis). J Wildl Dis 49:632-636

> Dearolf JL, McLellan WA, Dillaman RM, Frierson D Jr, Pabst DA (2000) Precocial development of axial locomotor muscle in bottlenose dolphins (Tursiops truncatus). J Morphol 244:203-215

Fauquier DA, Kinsel MJ, Dailey MD, Sutton GE, Stolen MK, Wells RS, Gulland FM (2009) Prevalence and pathology of lungworm infection in bottlenose dolphins Tursiops truncatus from southwest Florida. Dis Aquat Org 88: 85-90

Ficht TA, Husseinen HS, Derr J, Bearden SW (1996) Species-specific sequences at the omp2 locus of Brucella type strains. Int J Syst Bacteriol 46:329-331

Fire SE, Flewelling LJ, Wang Z, Narr J, Henry MS, Pierce RH, Wells RS (2008) Florida red tide and brevetoxins: association and exposure in live resident bottlenose dolphins (Tursiops truncatus) in the eastern Gulf of Mexico, USA. Mar Mamm Sci 24:831-24844

Fire SEWZ, Byrd M, Whitehead HR, Paternoster J, Morton SL (2011) Co-occurrence of multiple classes of harmful algal toxins in bottlenose dolphins (Tursiops truncatus) stranding during an unusual mortality event in Texas, USA. Harmful Algae 10:330-336

Fire SE, Pruden J, Couture D, Want Z and others (2012) Saxitoxin exposure in an endangered fish: association of a shortnose sturgeon mortality event with a harmful algal bloom. Mar Ecol Prog Ser 460:145-153 
Geraci JR, Lounsbury VJ (1993) Marine mammals ashore: a field guide for strandings. Texas A\&M University Sea Grant College Program, Galveston, TX

Goertz CE, Frasca S Jr, Bohach GA, Cowan DF and others (2011) Brucella sp. vertebral osteomyelitis with intercurrent fatal Staphylococcus aureus toxigenic enteritis in a bottlenose dolphin (Tursiops truncatus). J Vet Diagn Invest 23:845-851

Gould SJ (2007) The respiratory system. In: Keeling JW, Yee KT (eds) Fetal and neonatal pathology. Springer, London, p 531-570

- Guzmán-Verri C, González-Barrientos R, Hernández-Mora G, Morales JA, Baquero-Calvo E, Chaves-Olarte E, Moreno E (2012) Brucella ceti and brucellosis in cetaceans. Front Cell Infect Microbiol 2:3

> Hernández-Mora G, Palacios-Alfaro JD, Gonzalez-Barrientos R (2013) Wildlife reservoirs of brucellosis: Brucella in aquatic environments. Rev Sci Tech OIE 32:89-103

Jeffery HE Lahra, Monica M. (2007) The impact of infection during pregnancy on the mother and baby. In: Keeling JW, Yee KT (eds) Fetal and neonatal pathology. Springer, London, p 379-423

Keeling JW (2007) Intrapartum problems. In: Keeling JW, Yee KT (eds) Fetal and neonatal pathology. Springer, London, p 273-296

Keller-Wood M, Cudd TA, Norman W, Caldwell SM, Wood CE (1998) Sheep model for study of maternal adrenal gland function during pregnancy. Lab Anim Sci 48: 507-512

> Litz JA, Baran MA, Bowen-Stevens SR, Carmichael RH and others (2014) Review of historical unusual mortality events (UMEs) in the Gulf of Mexico (1990-2009): providing context for the multi-year northern Gulf of Mexico cetacean UME declared in 2010. Dis Aquat Org 112: 161-175

> Mattson MC, Mullin KD, Ingram GW Jr, Hoggard W (2006) Age structure and growth of the bottlenose dolphin (Tursiops truncatus) from strandings in the Mississippi sound region of the north-central Gulf of Mexico from 1986 to 2003. Mar Mamm Sci 22:654-666

> Maucher JM, Briggs L, Podmore C, Ramsdell JS (2007) Optimization of blood collection card method/enzyme-linked immunoassay for monitoring exposure of bottlenose dolhpin to brevetoxin-producing red tides. Environ Sci Technol 41:563-567

> Mazet JA, Gardner IA, Jessup DA, Lowenstine LJ (2001) Effects of petroleum on mink applied as a model for reproductive success in sea otters. J Wildl Dis 37:686-692

McBride AF, Kritzler H (1951) Observations of pregnancy, parturition, and post-natal behavior in the bottlenose dolphin. J Mammal 32:251-266

> McNutt MK, Chu S, Lubcheno J, Hunter T, Dreyfus G, Murawski SA, Kennedy DM (2012) Applications of science and enginerring to quantify and control the Deepwater Horizon oil spil. Proc Natl Acad Sci USA 109: 20222-20228

Meegan J, Dunn JL, Venn-Watson SK, Smith CR and others (2012) Serologic response in bottlenose dolphins Tursiops truncatus infected with Brucella sp. using a dolphin-specific indirect ELISA. Dis Aquat Org 102:73-85

> Michel J, Owens EH, Zengel S, Graham A and others (2013) Extent and degree of shoreline oiling: Deepwater Horizon oil spill, Gulf of Mexico, USA. PLoS ONE 8:e65087

Miller WG, Adams LG, Ficht TA, Cheville NF and others (1999) Brucella-induced abortions and infection in bot- tlenose dolphins (Tursiops truncatus). J Zoo Wildl Med 30:100-110

> Nymo IH, Tryland M, Godfroid J (2011) A review of Brucella infection in marine mammals, with special emphasis on Brucella pinnipedialis in the hooded seal (Cystophora cristata). Vet Res 42:93

Olsen SC, Palmer MV (2014) Advancement of knowledge of Brucella over the past 50 years. Vet Pathol 51:1076-1089

Pitchford JJ, Serafin BJS, Shannon D, Coleman AT, Solangi M (2013) An analysis of historical bottlenose dolphin (Tursiops truncatus) strandings in Mississippi Sound, USA using classification and regression trees (CART). J Cetacean Res Manag 13:201-209

Rhyan JC, Gidlewski T, Roffe TJ, Aune K, Philo LM, Ewalt DR (2001) Pathology of brucellosis in bison from yellowstone national park. J Wildl Dis 37:101-109

Samartino LE, Enright FM (1993) Pathogenesis of abortion of bovine brucellosis. Comp Immunol Microb Infect Dis 16:95-101

San Sebastián M, Armstrong B, Stephens C (2002) Outcomes of pregnancy among women living in the proximity of oil fields in the Amazon basin of Ecuador. Int $\mathrm{J}$ Occup Environ Health 8:312-319

Schlafer DH, Miller RB (2007) Female genital system. In: Maxie MG (ed) Jubb, Kennedy, and Palmer's pathology of domestic animals, Vol 3. Saunders Elsevier, St. Louis, MO, p 429-564

> Schwacke LH, Smith CR, Townsend FI, Wells RS and others (2014) Health of common bottlenose dolphins (Tursiops truncatus) in Barataria Bay, Louisiana, following the Deepwater Horizon oil spill. Environ Sci Technol 48: 93-103

> Schwartz JA, Aldridge BM, Stott JL, Mohr FC (2004) Immunophenotypic and functional effects of bunker $\mathrm{c}$ fuel oil on the immune system of American mink (Mustela vison). Vet Immunol Immunopathol 101:179-190

Sierra E, Sanchez S, Saliki JT, Blas-Machado U, Areblo M, Zucca D, Fernandez A (2014) Retrospective study of etiologic agents associated with nonsuppurative meningoencephalitis in stranded cetaceans in the Canary Islands. J Clin Microbiol 52:2390-2397

Skendros P, Boura P (2013) Immunity to brucellosis. Rev Sci Tech OIE 32:137-147

Smith CR, Jensen ED, Blakenship BA, Greenberg M and others (2013) Fetal omphalocele in a common bottlenose dolphin (Tursiops truncatus). J Zoo Wildl Med 44: 87-92

Tamura K, Stecher G, Peterson D, Filipski A, Kumar S (2013) MEGA6: molecular evolutionary genetics analysis version 6.0. Mol Biol Evol 30:2725-2729

> Twiner MJ, Fire SE, Schwacke L, Davidson L and others (2011) Concurrent exposure of bottlenose dolphins (Tursiops truncatus) to multiple algal toxins in Sarasota Bay, Florida, USA. PLoS ONE 6:e17394

> Van Dolah FM, Finley EL, Haynes BL, Doucette GJ, Moeller PD, Ramsdell JS (1994) Development of rapid and sensative high throughput pharmacologic assays for marine phycotoxins. Nat Toxins 2:189-196

Venn-Watson S, Garrison L, Litz J, Fougere E and others (2015a) Demographic clusters identified within the northern Gulf of Mexico common bottlenose dolphin (Tursiops truncatus) unusual mortality event: January 2010-June 2013. PLoS ONE 10:e0117248

Venn-Watson S, Colegrove KM, Litz J, Kinsel M and others (2015b) Adrenal gland and lung lesions in Gulf of Mexico 
common bottlenose dolphins (Tursiops truncatus) found dead following the Deepwater Horizon oil spill. PLoS ONE 10:e0126538

Wang Z, Maucher-Fuquay J, Fire SE, Mikulski CM, Haynes B, Doucette GJ, Ramsdell JS (2012) Optimization of solidphase extraction and liquid chromatography-tandem mass spectrometry for the determination of domoic acid in seawater, phytoplankton, and mammalian fluids and tissues. Anal Chim Acta 715:71-79

Wanke MM (2004) Canine brucellosis. Anim Reprod Sci 82-83:195-207

Worthy G (1998) Patterns of bottlenose dolphin, Tursiops truncatus, strandings in Texas. In: Zimmerman R (ed) Characteristics and causes of Texas marine strandings. Tech Rep NMFS 14. NOAA US Deparatment of Commerce, Seattle, WA

Xavier MN, Paixao TA, Poester FP, Lage AP, Santos RL (2009) Pathological, immunohistochemical and bacteriological study of tissues and milk of cows and fetuses experimentally infected with Brucella abortus. J Comp Pathol 140:149-157

Xu X, Cho SI, Sammel M, You L and others (1998) Association of petrochemical exposure with spontaneous abortion. Occup Environ Med 55:31-36

\section{Appendix 1}

${ }^{2}$ National Marine Mammal Foundation, San Diego, CA 92016, USA

${ }^{3}$ National Marine Fisheries Service, Southeast Fisheries Science Center, Miami, FL 33149, USA

${ }^{4}$ National Marine Fisheries Service, Southeast Regional Office, St. Petersburg, FL 70118, USA

${ }^{5}$ University of North Carolina Wilmington, Department of Biology and Marine Biology, Wilmington, NC 28403, USA

${ }^{6}$ Animal Health Center, 1787 Angus Campbell Road, Abbotsford, BC V3G 2M3, Canada,

${ }^{7}$ Athens Veterinary Diagnostic Laboratory College of Veterinary Medicine, University of Georgia, Athens, GA 30602, USA

${ }^{8}$ NOAA National Ocean Service, Charleston, SC 29412, USA

${ }^{9}$ NOAA Affiliate, Southeast Fisheries Science Center, Miami, FL 33149, USA

${ }^{10}$ NOAA Affiliate, Southeast Fisheries Science Center, Pascagoula, MS 39567, USA

${ }^{11}$ National Marine Fisheries Service, Silver Spring, MD 20910, USA

${ }^{12}$ Audubon Aquarium of the Americas, New Orleans, LA 70118, USA

${ }^{13}$ Dauphin Island Sea Lab and University of South Alabama, Dauphin Island, AL, USA

${ }^{14}$ Institute for Marine Mammal Studies, Gulfport, MS 39503, USA

${ }^{15}$ Louisiana Department of Wildlife and Fisheries, Baton Rouge, LA 70898, USA

${ }^{16}$ Mote Marine Laboratory, Sarasota, FL 34236, USA

${ }^{17}$ Present address: Florida Institute of Technology Department of Biological Sciences, Melbourne, FL 32901, USA

${ }^{18}$ Present address: The Marine Mammal Center, Fort Cronkhite, Sausalito, CA 94965, USA

Editorial responsibility: Michael Moore, Woods Hole, Massachusetts, USA
Submitted: August 17, 2015; Accepted: January 25, 2016

Proofs received from author(s): March 21, 2016 